\title{
Recombinant production of the therapeutic peptide lunasin
}

\author{
Stuart Kyle, Kier AR James and Michael J McPherson*
}

\begin{abstract}
Background: Lunasin is a chemopreventive peptide produced in a number of plant species. It comprises a helical region with homology to a region of chromatin binding proteins, an Arg-Gly-Asp cell adhesion motif and eight aspartic acid residues. In vitro studies indicate that lunasin suppresses chemical and oncogene driven transformation of mammalian cells. We have explored efficient recombinant production of lunasin by exploiting the Clostridium thermocellum CipB cellulose binding domain (CBD) as a fusion partner protein.

Results: We used a pET28 vector to express a CBD-lunasin fusion with a hexahistidine tag and Tobacco Etch Virus protease site, to allow protease-mediated release of native lunasin. Autoinduction in E. coli BL21 (DE3) Star cells achieved expression of $3.35 \mathrm{~g} / \mathrm{L}$ of CBD-lunasin fusion protein. The final yield of lunasin was $210 \mathrm{mg} / \mathrm{L}$ corresponding to $32 \%$ of the theoretical yield. Purification by cellulose binding and nickel affinity chromatography were tested with the latter proving more satisfactory.

The effects of CBD-lunasin expression on growth and morphology of the E. coli cells were examined by light and electron microscopy revealing an altered morphology in a proportion of cells. Cell division appeared to be inhibited in these cells resulting in elongated, non-septated cells.

Conclusions: The use of CBD as a fusion partner gave high protein yields by autoinduction, with lunasin release by TEV protease cleavage. With some optimisation this approach could provide a potentially valuable route for production of this therapeutic peptide. Over-expression in the host cells manifest as a cell division defect in a population of the cells, presumably mimicking some aspect of the chemopreventive function observed in mammalian cells.
\end{abstract}

Keywords: Lunasin, Autoinduction, E. coli, Cellulose binding domain, Chemopreventive peptide

\section{Background}

Lunasin is a 43 amino acid chemopreventive peptide initially identified in soybean and more recently in barley, wheat, and Solanum nigrum [1]. It is a small subunit peptide derived from the larger cotyledon-specific $2 S$ albumin (Gm2S-1) complex and comprises three distinct regions. An N-terminal helical region that shares homology with the conserved region of the chromatin binding proteins, an Arg-Gly-Asp (RGD) cell adhesion motif and a C-terminal sequence of eight aspartic acid (D) residues [2]. Various studies have shown the ability of lunasin to suppress both chemical and oncogene driven transformation of mammalian cells. The chemopreventive

\footnotetext{
* Correspondence: m.j.mcpherson@leeds.ac.uk

Astbury Centre for Structural Molecular Biology, Institute of Molecular and Cellular Biology, Faculty of Biological Sciences, University of Leeds, Leeds LS2
} 9JT, UK

(c) 2012 Kyle et al; licensee BioMed Central Ltd. This is an Open Access article distributed under the terms of the Creative Commons Attribution License (http://creativecommons.org/licenses/by/2.0), which permits unrestricted use, distribution, and reproduction in any medium, provided the original work is properly cited. properties have also been illustrated in mouse skin cancer models where lunasin has been shown to suppress transformation and subsequent carcinogenesis [3]. The proposed biological activity of the regions of lunasin is shown in Figure 1.

There are two broad strategies for the production of therapeutic peptides and proteins: chemical synthesis and recombinant production by transgenic organisms ranging from bacteria and fungi to plants and animals. Chemical synthesis is rapid and effective for the production of custom-made peptides in relatively small quantities but can be costly and problematic during process scale-up and as amino acid sequence length increases with sequences over 35 amino acids not generally considered to be economically feasible [5]. In addition, the process employs chemicals that present potential environmental hazards. The use of microbial 'biofactories' for

\section{Biomed Central}




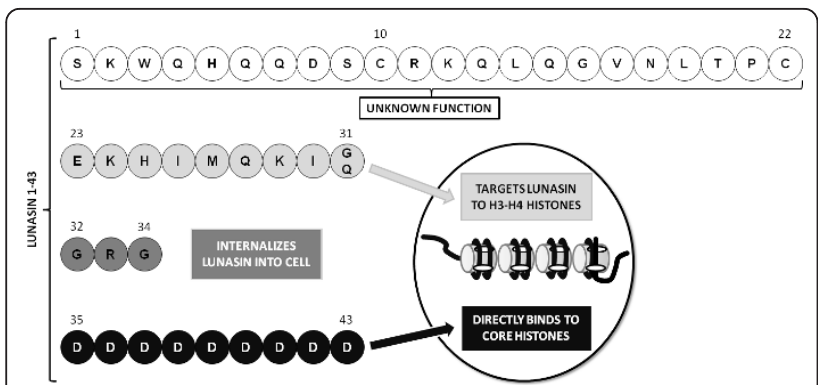

Figure 1 Amino acid sequence of lunasin and activity of regions of the peptide. Lunasin is a 43-amino acid peptide consisting of four regions. The function of residues $1-22$ is currently unknown. Residues 23-31 target lunasin to chromatin. The Arg-GlyAsp cell recognition sequence of residues 32-34 is known to internalise lunasin into the cell nucleus. The poly-aspartyl end of lunasin (residues 35-43) is responsible for binding it to the core histones within the chromatin. Adapted from [4].

protein synthesis is widely employed in industry owing to their ease of use, robustness and costs. Recombinant systems are more effective for the production of long peptides (> 35 amino acids) and proteins.

The Gram-negative bacterium E. coli is one of the most attractive systems for heterologous protein production due to its ability to grow rapidly to a high cell density on inexpensive substrates and it is genetically well characterised. A common strategy for the production of recombinant peptides involves genetic attachment to a well expressed protein to generate a fusion protein. The protein acts to protect the peptide from proteolytic digestion and can protect the host from potential toxicity associated with some peptides. There are a number of fusion partner proteins available which differ in size and properties; some facilitate soluble expression while others promote the formation of inclusion bodies [6-8].

Previous reports of lunasin expression in E. coli have included its fusion to an 8 amino acid FLAG peptide epitope to allow antibody detection. It was observed that the DH5 $\alpha$ host exhibited poor growth and an inability to septate, resulting in the formation of filamentous cells [9]. In another study, lunasin was expressed as a fusion to green fluorescent protein (GFP) using an in vitro transcription/translation reaction. While reasonable protein yields of $270 \mu \mathrm{g}$ of purified GFP-lunasin protein were obtained from a $10 \mathrm{~mL}$ reaction, this only equates to $27 \mathrm{mg} / \mathrm{L}$ of fusion protein and a theoretical maximum of $4.1 \mathrm{mg}$ of lunasin peptide. In addition the equipment and reagents required for this system are expensive which is likely to limit scale-up [10]. More recently lunasin has been expressed with a C-terminal His-tag in a soluble form and purified by immobilized metal affinity chromatography. Using an E. coli T7 system with IPTG induction, $4.73 \mathrm{mg}$ of lunasin was
expressed/L of culture [11]. This study showed that bacterial growth and expression levels were not affected by the presence of lunasin. In the present study, to enhance the levels of production of lunasin we have investigated the use of a His-tagged Clostridium thermocellum CipB cellulose binding domain (CBD) as a fusion protein and purification tag for the production of the native therapeutic peptide lunasin.

\section{Results}

\section{Cloning of CBD-lunasin into pET28c}

The lunasin coding sequence with an $\mathrm{N}$-terminal six histidine tag and TEV protease (TEVp) site was constructed by recursive PCR using the primers, EcHisTEVlunF and EcHisTEVlunR. This fragment was then cloned into pET28 downstream of the CBD coding region. DNA sequence analysis confirmed the integrity of the construct. Figure 2 shows a schematic representation of the recombinant protein expression and peptide release strategy.

\section{Expression of CBD-lunasin fusion protein from $E$. coli $B L 21 *$ (DE3) by auto-induction}

Auto-induction allows cultures to reach very high cell densities before recombinant protein expression occurs [12]. This approach reduces the risk of cell toxicity while enhancing product recovery.

Initial expression trials with TB media were conducted over a period of $72 \mathrm{~h}$ at $25^{\circ} \mathrm{C}$. This temperature has previously been shown to be optimal for the production of soluble CBD and CBD fusions within the laboratory (unpublished observations). It was apparent

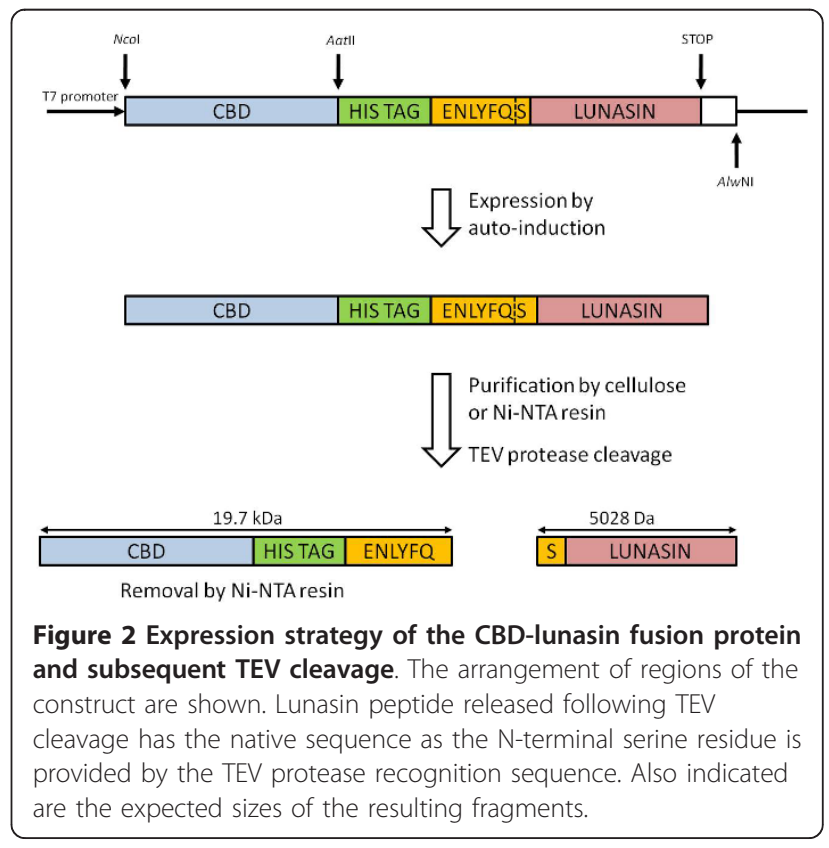




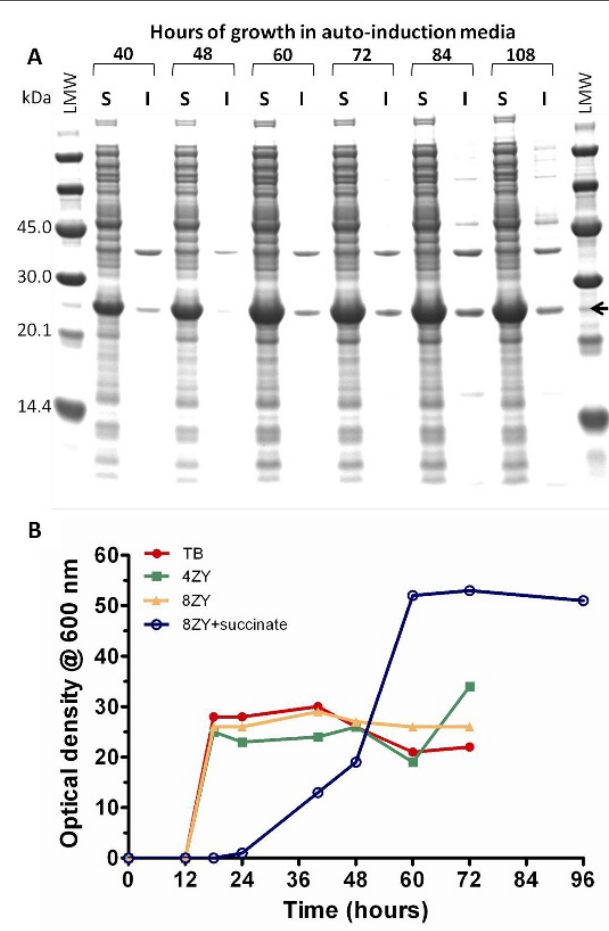

\section{C}
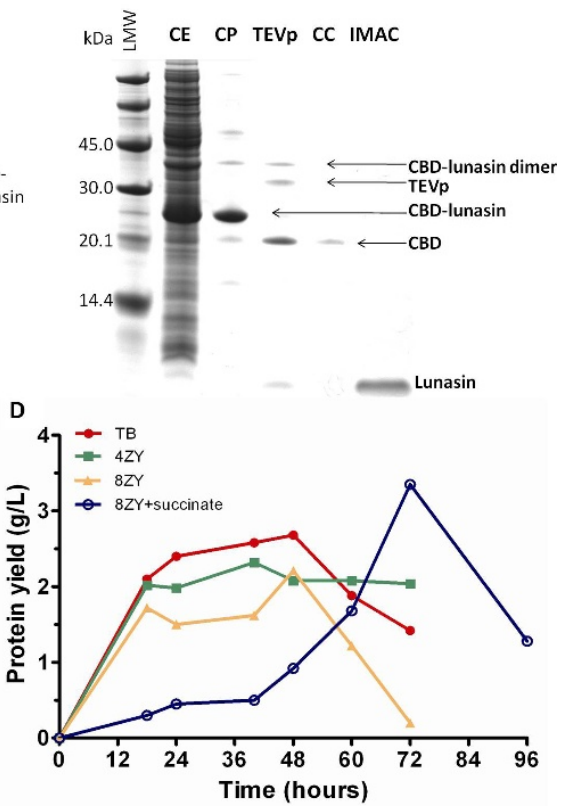

Figure 3 Expression of CBD-lunasin constructs and protein recovery. (A) SDS-PAGE analysis of soluble and insoluble fractions of E. coli BL21*(DE3) carrying pET28-CBD-lunasin grown on 8ZY auto-induction media supplemented with $4 \times 5052$ and succinate at $25^{\circ} \mathrm{C}$. (B) Timecourse of cell growth as OD600 in various auto-induction media at $25^{\circ} \mathrm{C}$ (C) SDS-PAGE analysis of the CBD-lunasin fusion protein purified using cellulose phosphate batch binding, cleavage by TEV protease and either a Microcon ${ }^{\circledR}$ concentrator column or Ni-NTA agarose step. (D) CBDlunasin fusion protein yield over time-course in (B).

from SDS-PAGE analysis that the majority of the fusion protein was in the soluble fraction with yields reaching $1.4 \mathrm{~g} / \mathrm{L}$ between 60 and $72 \mathrm{~h}$ of growth (Figure $3 \mathrm{~A})$.

From the work of Studier [12] and previous studies in our laboratory [13,14], it was clear that alternative basal media together with increased levels of carbon source could result in increased yields of fusion protein.

This was investigated with cultures grown over a period of $96 \mathrm{~h}$ at $25^{\circ} \mathrm{C}$ in four different media (TB, $4 \mathrm{ZY}$, $8 \mathrm{ZY}$ and $8 \mathrm{ZY}$ ). Samples were taken at regular intervals, and the culture optical densities at $600 \mathrm{~nm}$ (Figure 3B) and protein yields (Figure 3C) were determined. Maximal culture densities were obtained following $72 \mathrm{~h}$ growth at $25^{\circ} \mathrm{C}$, in $8 \mathrm{ZY}$ medium supplemented with $4 \times$ 5052 ( $2 \%$ glycerol, $0.2 \%$ glucose, $0.8 \% \alpha$-lactose monohydrate) and $25 \mathrm{mM}$ succinate (Table 1) [12]. This culture reached very high culture densities with an $\mathrm{OD}_{600}$ value of 53. SDS-PAGE analysis in conjunction with quantification of yields by densitometry revealed that this medium resulted in the production of $3.35 \mathrm{~g} / \mathrm{L}$ of CBD fusion protein at $72 \mathrm{~h}$. Purification of the CBDlunasin fusion protein resulted in a yield of $51.5 \%$ which equates to a maximum theoretical lunasin yield of 350 $\mathrm{mg} / \mathrm{L}$.

\section{Purification of CBD-lunasin fusion protein by batch} binding to cellulose

The low cost of cellulose makes this an attractive purification matrix and so we explored the recovery of the

Table 1 Components of auto-induction media.

\begin{tabular}{lcccc}
\hline Medium components & \multicolumn{5}{c}{ Growth Medium } \\
\hline & TB & $\mathbf{4 Z Y}$ & $\mathbf{8 Z Y}$ & $\mathbf{8 Z Y}+$ succinate \\
\hline Tryptone $(\mathrm{g} / \mathrm{L})[\mathrm{Z}]$ & 12 & 40 & 80 & 80 \\
\hline Yeast extract $(\mathrm{g} / \mathrm{L})[\mathrm{Y}]$ & 24 & 20 & 40 & 40 \\
\hline $\mathrm{NPCS}(\mathrm{mM})$ & & & & \\
\hline $\mathrm{Na}_{2} \mathrm{HPO}_{4}$ & 25 & 25 & 25 & 25 \\
\hline $\mathrm{KH}_{2} \mathrm{PO}_{4}$ & 25 & 25 & 25 & 25 \\
\hline $\mathrm{NH}_{4} \mathrm{Cl}$ & 50 & 50 & 50 & 50 \\
\hline $\mathrm{Na}_{2} \mathrm{SO}_{4}$ & 5 & 5 & 5 & 5 \\
\hline $\mathrm{MgSO}_{4}(\mathrm{mM})$ & 2 & 2 & 2 & 2 \\
\hline Trace metals & $0.2 \times$ & $0.2 \times$ & $0.2 \times$ & $0.2 \times$ \\
\hline $5052(\%)$ & & & & \\
\hline Glycerol & 2 & 2 & 2 & 2 \\
\hline Glucose & 0.2 & 0.2 & 0.2 & 0.2 \\
\hline Lactose & 0.8 & 0.8 & 0.8 & 0.8 \\
\hline Succinate $(\mathrm{mM})$ & - & - & - & 25 \\
\hline Adapted from $[121$ & & & &
\end{tabular}

Adapted from [12] 
CBD-lunasin using cellulose. Following cell lysis the supernatant was diluted 2-fold with $200 \mathrm{mM}$ Tris- $\mathrm{HCl}$ ( $\mathrm{pH} 7.0)$ and prewetted cellulose phosphate was added to a final concentration of $200 \mathrm{mg} / \mathrm{mL}$. After binding overnight at room temperature, the cellulose phosphate was washed twice with $100 \mathrm{mM}$ Tris- $\mathrm{HCl}$ ( $\mathrm{pH}$ 7.0) (Figure 3D). A number of elution steps typically 4 , each with $25 \mathrm{~mL}$, water were required to release around 50 $\mathrm{mg}$ of the protein thus resulting in a significant dilution of the fusion protein.

We therefore explored purification using nickel affinity chromatography (Ni-NTA) by exploiting the histidine tag. This allowed the more efficient recovery of concentrated fusion protein, with some evidence on SDS-PAGE of dimers and trimers of the fusion protein (Figure 3D).

TEV cleavage of the lunasin peptide from the CBD fusion protein results in release of lunasin with a native $\mathrm{N}$-terminal serine provided by the TEV protease site ENLYFQ/S (Figure 2). TEV protease cleavage was conducted at room temperature over a $24 \mathrm{~h}$ time-period with a TEV protease concentration of $700 \mathrm{nM}$. Reasonably efficient cleavage was achieved although low levels of uncleaved fusion protein remained (Figure 3D). The dimeric form of the fusion protein appeared not to be susceptible to cleavage perhaps due to steric interactions between monomers occluding the protease sites.

Following TEV cleavage the lunasin peptide was separated from CBD, TEVp and uncut CBD-lunasin. Two approaches were investigated; the first was Microcon ${ }^{\circledR}$ centrifugal filter devices that have a cellulose matrix acting as a molecular sieve to allow passage of molecules of less than $10 \mathrm{kDa}$, such as lunasin, whilst retaining larger molecules. The second approach was Ni-NTA agarose batch binding as all the proteins contain a His tag whilst lunasin does not and so would remain in solution (Figure 3D).

The Microcon ${ }^{\circledR}$ centrifugal approach was ineffective as the majority of the peptide was retained. In contrast, batch binding with the Ni-NTA agarose proved to be quite efficient with $60 \%$ of the lunasin being recovered, corresponding to a yield of $210 \mathrm{mg} / \mathrm{L}$ culture.

To confirm the molecular mass and purity of the final lunasin product, mass spectrometry was performed and revealed a single major peak corresponding to 5024.09 $\mathrm{Da}$ in excellent agreement with the calculated mass of 5028.36 Da.

\section{Effect of lunasin on E. coli cell morphology}

To check for any effect of the CBD-lunasin fusion on the growth and morphology of the E. coli BL21*(DE3) host cells, culture pellets were re-suspended in water and Gram stained (Figure 4A). By light microscopy it was apparent that expression of the CBD-lunasin fusion protein resulted in an altered morphology of some cells. Cell division appeared to be inhibited in a proportion of the cells resulting in elongated, non-septated cells with lengths of over $100 \mu \mathrm{M}$. In comparison, a Gram stain of E. coli BL21* (DE3) expressing CBD alone did not show such elongated, non-septate cells (Figure 4B).

To further investigate the morphology of these elongated $E$. coli cells, samples were visualized by transmission electron microscopy (TEM) (Figure 4C). Many of the cells appeared able to successfully undergo cell division as the invaginations of the cell wall, which precede cell division, were observed. In contrast no such invaginations of the cell wall were present in the elongated $E$. coli cells indicating that cell division had been inhibited. Lunasin does not appear to elicit an inhibitory effect on cell division phenotype in all host cells.

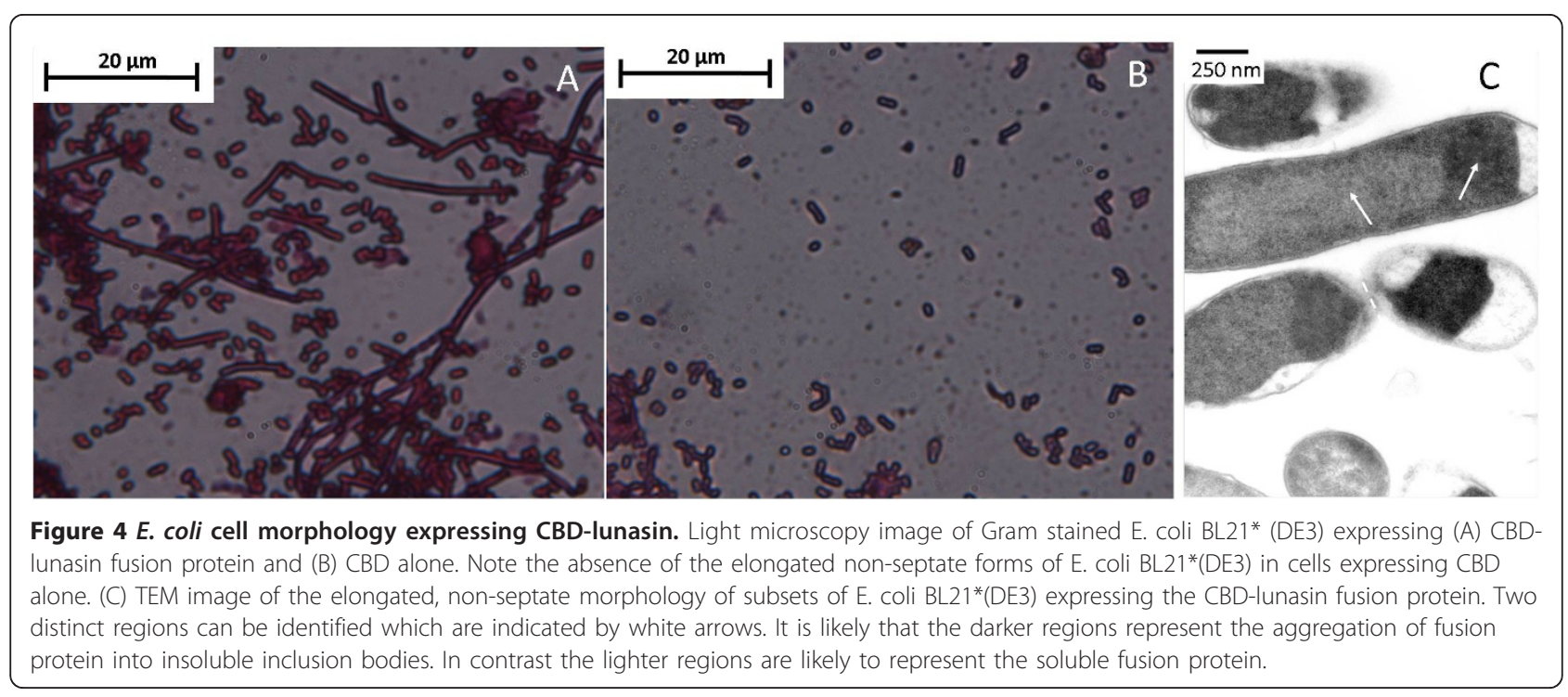




\section{Discussion}

In this work, the $C$. thermocellum derived CBD protein was used as a fusion partner for the expression of the therapeutic peptide lunasin. The CBD protein appears to reduce the previously observed toxicity of the lunasin peptide [15], as extremely high cell culture densities were obtained $\left(\mathrm{OD}_{600}\right.$ of 53$)$ with correspondingly high recovery of fusion protein. From the growth curves the highest culture densities and yields were obtained from cultures grown in very rich $8 \mathrm{ZY}$ medium supplemented with $4 \times 5052$ and succinate. However, use of this medium does result in a prolonged initial growth lag phase and so simpler TB medium may prove more suitable for large scale applications. Although the culture densities are lower for this medium it more rapidly reaches its maximal culture density. The culture time saved together with the lower cost of TB medium may compensate for the reduced peptide yields.

The use of the CBD fusion protein potentially offers significant advantages for the production of lunasin and other peptides. The ease of the batch purification procedure and the high degree of purity of the final product in conjunction with a cheap and abundant cellulose purification matrix are highly desirable for scale-up production. One challenge with this approach is determining efficient elution conditions that do not result in large volumes of dilute protein. In this regard the nickel affinity purification was more appropriate with around 50\% recovery of fusion protein. Improvements in peptide recovery might be achieved by combining cellulose affinity with on column cleavage followed by immobilised metal affinity chromatography (IMAC) to remove contaminants. As recovery of peptide was only $60 \%$ from the IMAC step, some of the target peptide may bind non-specifically to the IMAC resin resulting in peptide loss and so separation by alternative chromatographic approaches following TEV cleavage could be explored. A final Detoxi gel ${ }^{\mathrm{TM}}$ column would allow the removal of endotoxins resulting in a highly purified peptide solution that could then be used for cell-based assays and ultimately in vivo models.

From visualisation of $E$. coli cells expressing the CBDlunasin, it was apparent that the lunasin peptide can exert a significant effect on cell morphology, but this was only apparent in a subpopulation of cells. A similar phenotype has been observed in E. coli strains carrying mutations in the filamentous temperature sensitive (Fts) $\mathrm{Z}$ gene [16]. The FtsZ gene shares homology with the tubulins of eukaryotic cells and has led to the proposal that lunasin may have a similar effect on eukaryotic cells as FtsZ mutations in bacteria $[9,16]$. Lunasin expression in E. coli has a similar cytokinesis inhibitory effect that can be prevented by the removal of the poly- aspartyl tail of lunasin, indicating that aberrant cell division is attributable to this acidic domain [9]. The elongated phenotype could be due to the direct interaction of lunasin with one or more of the proteins or may be indirect due to interactions with other protein(s) within E. coli perhaps preventing Fts $Z$ gene transcription. Clearly the effect on cell division is variable as this was not observed in a recent study [11]. Our observations reveal that only a sub-population show the elongated morphology. This could be due to a dosage effect perhaps reporting the release of lunasin from the fusion protein, such that in a subpopulation of cells higher levels of lunasin are released and reach a threshold level able to mediate the observed phenotype. Further investigation of the difference observed between the various lunasin expression studies with regard to aberrant cell division would be required to understand this phenomenon.

The altered cell morphology may explain the very high culture densities observed as the elongated cells may alter the relationship between $\mathrm{OD}_{600}$ and cell number. The next stage will be to compare the efficacy of the recombinantly produced peptide with that from native sources such as soybean. For example through in vitro trials on cancer cell lines such as human breast cancer MCF-7 cells to determine whether cell division is inhibited and subsequently in vivo testing perhaps utilising skin cancer mouse models.

\section{Conclusions}

The CBD protein has been used as a successful fusion partner for the production of the chemopreventive peptide lunasin resulting in yields of peptide of upto 210 $\mathrm{mg} / \mathrm{L}$. Optical densities and protein yields were found to be enhanced when basal media was supplemented with $4 \times 5052$ and with succinate. However, these yields could potentially be increased further in bioreactors where oxygen and nutrient levels can be tightly regulated. This study highlights the potential for producing a therapeutic peptide in a prokaryotic system and may be of general applicability for a range of other therapeutic peptides.

\section{Methods}

\section{Bacterial strains, plasmids and cell culture media}

E. coli XL1 Blue (Stratagene, La Jolla, CA) was used for routine cloning. E. coli BL21Star (DE3) (Invitrogen, Carlsbad, CA) was used as the expression strain. The expression vector pET28c was from Novagen, Madison, WI and pGEM-T Easy from Promega.

The auto-induction growth media Terrific Broth (TB), 4ZY, 8ZY, 8ZY supplemented with succinate were prepared according to [12]. The composition of various 
auto-induction media are given in Table 1. Kanamycin and carbenicillin were added to media to a final concentration of $50 \mu \mathrm{g} / \mathrm{mL}$ as appropriate Cultures were grown in an orbital incubator at $37^{\circ} \mathrm{C}$ with shaking at $220 \mathrm{rpm}$ unless otherwise stated.

\section{Construction of plasmid $\mathrm{pET} 28 \mathrm{c} / \mathrm{CBD} / \mathrm{his} / \mathrm{TEV}$}

We used a plasmid generated in the laboratory by Dr. J. Riley. pET28c/rub/His/TEV was restricted with NcoI and AatIIand treated with antarctic phosphatase (New England BioLabs, Hitchin, UK) to generate the plasmid backbone. A pUC57 plasmid containing the C. thermocellum CBD coding sequence codon optimised for expression in E. coli (GenScript, Piscataway, NJ) was restricted with the same enzymes and the CBD insert was gel extracted, purified using a QIAquick Gel Extraction Kit (Qiagen, Crawley, UK) and ligated into the vector.

Following transformation into E. coli XL-1 blue cells, kanamycin resistant colonies were screened by colony PCR using T7 forward (TAATACGACTCAACTATAGGG), T7 reverse (GCTAGTTATTGCTCAGCGG) primers. Clones generating a 814 bp band were then confirmed by DNA sequencing on an ABI 3100XL Capillary Sequencer (DNA Sequencing Facility, Biological Sciences, University of Leeds).

\section{Gene synthesis by recursive PCR}

In order to generate the lunasin coding sequence, recursive PCR was performed with two primers, EcHisTEVlunf (GCGACGTCCATCACCATCACCATCACGAAAACCTGTATTTTCAGAGCAAATGGC AGCATCAGCAAGATAGCTGCCGCAAACAGCTG-

CAGGGCGTGAATCTGAC) and EcHisTEVlunR (GCACAGTGACTGTTATTAATCATCGTCATCATCATCGTCATCATCGCCGCGGCCC

TGAATCTTTTCCATGATATGTTTTTCGCACGGGGTCAGATTCACGC) possessing 13 bp complementary regions at their 3' ends (underscored). Primers were added to a final concentration of $0.3 \mu \mathrm{M}$ to a PCR reaction mixture consisting of $1 \times \mathrm{KOD}$ Hot Start DNA polymerase buffer $(20 \mathrm{mM}$ Tris- $\mathrm{HCl}(\mathrm{pH} 7.5$ at $25^{\circ} \mathrm{C}$ ), $8 \mathrm{mM} \mathrm{MgCl} 2,0.5 \mathrm{mM} \mathrm{DTT}, 50 \mathrm{mg} / \mathrm{mL} \mathrm{BSA}$ ) (Novagen), $0.2 \mathrm{mM}$ each dNTP, $1 \mathrm{mM}$ MgSO4 and $1 \mathrm{U}$ KOD Hotstart DNA polymerase and made up to $50 \mu \mathrm{L}$ with sterile ddH2O. PCR was performed in a G-storm GS2 PCR machine (Gene Technologies) at $95^{\circ} \mathrm{C}$ for 5 min then $39-45^{\circ} \mathrm{C}$ for $30 \mathrm{~s}$ and $72^{\circ} \mathrm{C}$ for $1 \mathrm{~min}$.

The PCR product was cloned into pGEM T easy according to the manufacturer' guidelines (Promega) transformed into E. coli XL-1 blue cells. Colonies containing recombinant plasmids were identified by colony PCR, as above, with the primers T7 Forward and SP6 promoter (ATTTAGGTGACAGTATAGAATAC). The insert was recovered by $A a t \mathrm{II}$ and $A l w \mathrm{NI}$ restriction digestion ligation into similarly digested pET28c/CBD/ His/TEVp vector. Following colony PCR screening the sequence of pET28c/CBD/His/TEVp/lunasin was confirmed by DNA sequencing.

\section{E. coli expression of pET28c constructs by auto-induction}

The protocols described by [12] were followed. LB plates with kanamycin $(50 \mu \mathrm{g} / \mathrm{mL})$ were streaked from glycerol stocks and grown overnight. A single colony was used to inoculate $2 \mathrm{~mL}$ of LB medium with kanamycin $\left(50 \mu \mathrm{g} / \mathrm{mL}\right.$ and grown at $37^{\circ} \mathrm{C}, 200 \mathrm{rpm}$ for $6 \mathrm{~h}$. A $200 \mu \mathrm{L}$ aliquot of this starter culture was then used to inoculate $400 \mathrm{~mL}$ of TB, $4 \mathrm{ZY}, 8 \mathrm{ZY}$ or $8 \mathrm{ZY}$ supplemented with $25 \mathrm{mM}$ succinate and auto-induction media components (Table 1 ) in baffled flasks. Cultures were grown at $25^{\circ} \mathrm{C}$ in an orbital incubator at $250 \mathrm{rpm}$. Samples of $1 \mathrm{~mL}$ were taken at regular intervals and the cell pellets stored at $-20^{\circ} \mathrm{C}$ for time course expression analysis by SDS-PAGE. After 60-96 h the cultures were harvested by centrifugation, $5000 \times g$ for $20 \mathrm{~min}$ at $4^{\circ} \mathrm{C}$ and the cell pellets stored at $-80^{\circ} \mathrm{C}$ prior to processing.

\section{E. coli expression of TEV protease and protein concentration analysis}

Expression of TEV protease was performed according to the method devised by [17]. Initially two pre-cultures of $5 \mathrm{~mL}$ LB containing ampicillin $(100 \mu \mathrm{g} / \mathrm{mL})$ and chloramphenicol $(34 \mu \mathrm{g} / \mathrm{mL})$ were grown over night at $37^{\circ} \mathrm{C}$ and used to inoculate two $500 \mathrm{~mL}$ volumes of LB in $2 \mathrm{~L}$ flasks. These cultures were grown to an $\mathrm{OD}_{600}$ of 0.6 and IPTG was added to a final concentration of $1 \mathrm{mM}$ and the temperature reduced to $20^{\circ} \mathrm{C}$ for $20 \mathrm{~h}$. The cells were then harvested by centrifugation at $5000 \times g$ for 15 $\min \left(4^{\circ} \mathrm{C}\right)$ and re-suspended in $40 \mathrm{~mL}$ of lysis buffer $(50$

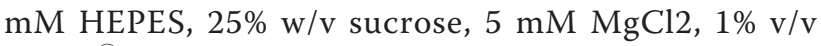
Triton ${ }^{\circledR}$ X-100 at pH 8.0 supplemented with 200 units/ $\mathrm{mL}$ of Omnicleave nuclease (Epicentre, Cambridge, UK) and $1 \mathrm{mg} / \mathrm{mL}$ of lysozyme, prior to use). After cell lysis for $3 \mathrm{~h}$ on a 'Roller Mixer SRT1' (Stuart Scientific) at $4^{\circ}$ $C$ cell debris was removed by centrifugation at $15,000 \times$ $g$ for $30 \mathrm{~min}$. The supernatant was dialysed into $5 \mathrm{~L}$ of $\mathrm{dH}_{2} \mathrm{O}$ containing $50 \mathrm{mM} \mathrm{NaH} \mathrm{PO}_{4}, 300 \mathrm{mM} \mathrm{NaCl}, \mathrm{pH}$ 7.0 at $4^{\circ} \mathrm{C}$ overnight and subsequently purified by nickel affinity chromatography. Following purification, EDTA and DTT were added to a concentration of 2 and 10 $\mathrm{mM}$ respectively. The eluate was then dialysed against 5 $\mathrm{L}$ of $\mathrm{dH}_{2} \mathrm{O}$ containing $25 \mathrm{mM} \mathrm{NaH}_{2} \mathrm{PO}_{4}, 200 \mathrm{mM} \mathrm{NaCl}$, $2 \mathrm{mM}$ EDTA and $2 \mathrm{mM}$ DTT (pH 7.0) over night at $4^{\circ}$ C. Samples were concentrated to $30 \mu \mathrm{M}$ using an 'Amicon Ultra ${ }^{\circledR}$, centrifugal device with a molecular cut off point of $3500 \mathrm{Da}$.

The protein concentration was determined spectrophotometrically and calculated using the extinction 
coefficient $\varepsilon_{280}=36130 \mathrm{M}^{-1} \mathrm{~cm}^{-1}$ [17] in conjunction with the Beer-Lambert law $(\mathrm{A}=\varepsilon \mathrm{cl})$.

\section{Analysis of soluble and insoluble cell proteins}

Cells were harvested at $5000 \times g$ for $15 \mathrm{~min}\left(4^{\circ} \mathrm{C}\right)$ in a fixed angle rotor and lysed in lysis buffer as above using $5 \mathrm{ml} / \mathrm{g}$ of cell pellet for $3 \mathrm{~h}$ at $4^{\circ} \mathrm{C}$. After centrifugation at $15,000 \times g$ for $30 \mathrm{~min}$ the supernatant represented the soluble fraction. The pellets representing the insoluble fraction was resuspended in the original volume of lysis buffer supplemented with $8 \mathrm{M}$ urea at $4^{\circ} \mathrm{C}$ with agitation for $2 \mathrm{~h}$ to solubilise insoluble fusion protein. Equal volumes of soluble and insoluble fractions were analysed by SDS-PAGE.

\section{SDS-PAGE analysis of protein expression and densitometry analysis}

Protein samples were heated at $95^{\circ} \mathrm{C}$ for $10 \mathrm{~min}$ in loading buffer consisting of $40 \%$ SDS, $20 \% \beta$-mercaptoethanol, $20 \%$ glycerol, and $0.01 \%$ of bromophenol blue in 1 M Tris-HCl (pH 6.8) before analysis on NuPAGE ${ }^{\circledR} 12 \%$ Bis-Tris gels (Invitrogen, Paisley, UK) at $200 \mathrm{~V}$ for 45 min. Protein bands were visualised using SimplyBlue ${ }^{\mathrm{TM}}$ SafeStain (Invitrogen, Paisley, UK) and protein concentrations estimated by densitometry using the AlphaImager Spot Denso software. The intensities of the bands were compared to those of known concentrations of low molecular weight protein standards (GE healthcare).

\section{Protein purification}

\section{Batch binding to cellulose phosphate}

Cellulose phosphate was added $(200 \mathrm{mg} / \mathrm{mL})$ directly to soluble cell extract samples and incubated at room temperature with agitation for $2 \mathrm{~h}$ to allow binding of CBD to the cellulose. The cellulose was then washed twice with $10 \mathrm{mM}$ sodium phosphate buffer ( $\mathrm{pH} 8.0$ ), with gentle agitation for 20 min followed by centrifugation at $7000 \times g$ for $10 \mathrm{~min}$ at $4^{\circ} \mathrm{C}$ and the wash buffer was decanted. Finally, the bound protein was eluted by addition of cold $\mathrm{dd}_{2} \mathrm{O}$ and incubation for $1 \mathrm{~h}$ at $4^{\circ} \mathrm{C}$. This step was repeated up to three times to improve protein recovery. Resulting purified fractions were analysed by SDS-PAGE. Where protein solutions were too dilute 'Microcon ${ }^{\circledR}$ ' and 'Amicon Ultra ${ }^{\circledR}$ ' centrifugal devices was used according to the manufacturers' guidelines, for volumes below and above $1 \mathrm{~mL}$ respectively, to concentrate the samples.

\section{Nickel affinity chromatography (Ni-NTA)}

Purification of His-tagged polypeptides and proteins was achieved by using a $5 \mathrm{~mL}$ HiTrap $^{\mathrm{TM}}$ column containing Chelating Sepharose ${ }^{\mathrm{TM}}$ High Performance (GE Healthcare). Protein samples were resuspended in binding buffer $(20 \mathrm{mM}$ Tris- $\mathrm{HCl}, 0.5 \mathrm{M} \mathrm{NaCl}, 5 \mathrm{mM}$ imidazole, 1 $\mathrm{mM} \beta$-mercaptoethanol, $\mathrm{pH} 8$ ) and loaded onto the column followed by extensive washing with binding buffer containing $20 \mathrm{mM}$ imidazole to remove non-specifically bound proteins. The bound proteins were eluted by applying a $0-100 \%$ gradient $(20 \mathrm{mM}-500 \mathrm{mM})$ over $50 \mathrm{~mL}$ of buffer and $1 \mathrm{~mL}$ fractions were collected. Fractions containing protein were analysed by SDSPAGE analysis. Protein concentrations were determined by using the Bradford assay reagent (Sigma-Aldrich).

\section{TEV cleavage of peptide constructs}

Cleavage experiments were performed according to [17]. TEV protease was used at a final concentration of 700 $\mathrm{nM}$ in TEV protease cleavage buffer $(25 \mathrm{mM} \mathrm{NaPi}, 125$ $\mathrm{mM} \mathrm{NaCl}$, and $5 \mathrm{mM}$ DTT, $\mathrm{pH}$ 7.4) at room temperature.

\section{Mass spectrometry}

Peptide samples were first concentrated using C18 ZipTip (Millipore UK, Ltd.) and eluted in 50\% methanol/ $0.1 \%$ aqueous formic acid and then analysed by positive ionisation nanoelectrospray using an LCT Premier mass spectrometer (Waters Corporation, Manchester, UK). Samples were infused using a NanoMate (Advion Biosciences Inc., Ithaca, NY) autosampler and ionisation interface which was maintained at $4^{\circ} \mathrm{C}$. A capillary voltage of $1.8 \mathrm{kV}$ was set with a nitrogen gas flow of 0.4 psi for sample introduction and ionisation. The sampling cone voltage was optimised at $20 \mathrm{~V}$, Ion Guide 1 was at $130 \mathrm{~V}$ and Aperture 1 was at $60 \mathrm{~V}$. Data were acquired over the $\mathrm{m} / \mathrm{z}$ range 500-5000, and data processing was performed using the MassLynx software supplied with the mass spectrometer. An external calibration using sodium iodide clusters was applied to the data.

\section{Gram-staining and light microscopy}

Cultures $(10 \mu \mathrm{l})$ containing E. coli BL21* (DE3) was smeared onto a slide and heat fixed. Crystal violet solution was applied and allowed to stand for $1 \mathrm{~min}$ before extensive washing. The slide was then flooded with iodine solution and allowed to stand for $1 \mathrm{~min}$ before rinsing again. The slide was then decolourised with acetone for $5 \mathrm{~s}$ and immediately rinsed with distilled water. Safranin was applied and allowed to stand for $30 \mathrm{~s}$ before a final rinse with distilled water. Bacterial slides were examined using a light microscope (Olympus, BX51) under a $100 \times$ objective.

\section{Transmission electron microscopy}

E. coli cells in growth media were harvested by centrifugation at $17,900 \times g$ for $2 \mathrm{~min}$ in microcentrifuge tubes. Cells were subsequently washed twice with $\mathrm{dH}_{2} \mathrm{O}$ then fixed with $2.5 \%$ glutaraldehyde for $3 \mathrm{~h}$ followed by washing twice with $0.1 \mathrm{M}$ phosphate buffer $(\mathrm{pH} 7.0)$ for 30 
min each followed by centrifugation at $6,000 \times g$ for 5 min to collect the cells. Cell samples were incubated in $1.0 \%$ osmium tetraoxide solution overnight followed by washing twice with $0.1 \mathrm{M}$ phosphate buffer and harvested by centrifugation at $6,000 \times g$ for $5 \mathrm{~min}$.

Samples were then dehydrated by incubating in ascending concentrations of ethanol (20\%, 40\%, 60\%, $80 \%$, and $100 \%$ twice) for 30 min each. Dehydration of the samples was followed by two incubations in propylene oxide for $30 \mathrm{~min}$ followed by centrifugation at $6,000 \times g$ for 5 min to harvest the cells. Embedding was achieved by incubating in a 50\%:50\% mix of propylene oxide and araldite overnight. Samples were then incubated in a 75\%: $25 \%$ araldite:propylene mix for $3 \mathrm{~h}$. Finally, samples were re-suspended in fresh araldite and transferred to embedding moulds and incubated overnight at $60^{\circ} \mathrm{C}$ to set. The embedded cells were sectioned using a microtome and placed onto Glow-discharged carbon coated copper TEM grids for visualization using a Philips CM10 TEM operating at $80 \mathrm{kV}$.

\section{Abbreviations}

CBD: Cellulose Binding Domain; FtsZ gene: Filamentous temperature sensitive Z gene; IMAC: Immobilised Metal Affinity chromatography; Ni-NTA: Nickel Nitrilotriacetic Acid; TEV(p): Tobacco Etch Virus (protease); 5052: 0.5\% glycerol: $0.05 \%$ glucose: $0.2 \%$ a-lactose monohydrate.

\section{Acknowledgements}

SK was supported by a Wellcome Trust studentship (078114/Z/05/Z). KARJ was supported by a BBSRC studentship.

\section{Authors' contributions}

SK assisted with microscopy analysis and wrote the paper. KARJ performed experimental work. MJM devised and co-ordinated the study and edited the paper. All authors read and approved the final manuscript.

\section{Competing interests}

The authors declare that they have no competing interests.

Received: 31 October 2011 Accepted: 29 February 2012

Published: 29 February 2012

\section{References}

1. Jeong JB, Jeong HJ, Park JH, Lee SH, Lee JR, Lee HK, Chung GY, Choi JD, de Lumen BO: Cancer-preventive peptide lunasin from Solanum nigrum L. inhibits acetylation of core histones $\mathrm{H} 3$ and $\mathrm{H} 4$ and phosphorylation of retinoblastoma protein (Rb). J Agric Food Chem 2007, 55:10707-10713.

2. Jeong HJ, Park JH, Lam Y, de Lumen BO: Characterization of lunasin isolated from soybean. J Agric Food Chem 2003, 51:7901-7906.

3. Galvez AF, Chen N, Macasieb J, de Lumen BO: Chemopreventive property of a soybean peptide (lunasin) that binds to deacetylated histones and inhibits acetylation. Cancer Res 2001, 61:7473-7478.

4. Hernandez-Ledesma B, Hsieh CC, de Lumen BO: Lunasin, a novel seed peptide for cancer prevention. Peptides 2009, 30:426-430.

5. Kyle S, Aggeli A, Ingham E, McPherson MJ: Production of self-assembling biomaterials for tissue engineering. Trends Biotechnol 2009, 27:423-433.

6. Ingham $A B$, Moore RJ: Recombinant production of antimicrobial peptides in heterologous microbial systems. Biotechnol Appl Biochem 2007, 47:1-9.

7. Rodriguez-Carmona E, Cano-Garrido O, Seras-Franzoso J, Villaverde A, Garcia-Fruitos E: Isolation of cell-free bacterial inclusion bodies. Microb Cell Fact 2010, 9:71.

8. Garcia-Fruitos E: Inclusion bodies: a new concept. Microb Cell Fact 2010, 9:80.
9. Galvez AF, de Lumen BO: A soybean CDNA encoding a chromatinbinding peptide inhibits mitosis of mammalian cells. Nat Biotechnol 1999, 17:495-500.

10. Martin GA, Kawaguchi R, Lam Y, DeGiovanni A, Fukushima M, Mutter W: High-yield, in vitro protein expression using a continuous-exchange, coupled transcription/translation system. Biotechniques 2001, 31:948-953.

11. Liu C-F, Pan T-M: Recombinant expression of bioactive peptide lunasin. Appl Microbiol Biotechnol 2010, 88:177-186.

12. Studier FW: Protein production by auto-induction in high density shaking cultures. Protein Expr Purif 2005, 41:207-234.

13. Riley JM, Aggeli A, Koopmans RJ, McPherson MJ: Bioproduction and characterisation of a $\mathrm{pH}$ responsive self-assembling peptide. Biotechnol Bioeng 2009, 103:241-251.

14. Kyle S, Aggeli A, Ingham E, McPherson MJ: Recombinant self-assembling peptides as biomaterials for tissue engineering. Biomaterials 2010, 31:9395-9405.

15. Hsieh CC, Hernandez-Ledesma B, de Lumen BO: Soybean peptide lunasin suppresses in vitro and in vivo 7,12-dimethylbenz[a]anthracene-induced tumorigenesis. J Food Sci 2010, 75:H311-H316.

16. Erickson HP: FtsZ, a tubulin homologue in prokaryote cell division. Trends Cell Biol 1997, 7:362-367.

17. van den Berg S, Lofdahl PA, Hard T, Berglund H: Improved solubility of TEV protease by directed evolution. J Biotechnol 2006, 121:291-298.

\section{doi:10.1186/1475-2859-11-28}

Cite this article as: Kyle et al:: Recombinant production of the therapeutic peptide lunasin. Microbial Cell Factories 2012 11:28.

\section{Submit your next manuscript to BioMed Central and take full advantage of:}

- Convenient online submission

- Thorough peer review

- No space constraints or color figure charges

- Immediate publication on acceptance

- Inclusion in PubMed, CAS, Scopus and Google Scholar

- Research which is freely available for redistribution 